\title{
AKTIVITAS ANTIBAKTERI EKSTRAK ETIL ASETAT UMBI BAWANG DAYAK (Eleutherine palmifolia (L.) Merr) TERHADAP PERTUMBUHAN Escherichia coli
}

\section{Antibacterial Activity of Ethyl Acetate Extract of Dayak Onion Bulbs (Eleutherine palmifolia (L.) Merr) Against Escherichia coli Growth}

\author{
Alifa Purwahari Putri ${ }^{1, *}$, Yusianti Silviani ${ }^{2}$ \\ *email : alifapurwahari@gmail.com ${ }^{1,}{ }^{*}$, yusianti.silviani@gmail.com ${ }^{2}$ \\ $\underline{1,2}$ Laboratorium, Analis Kesehatan, STIKES Nasional
}

\begin{abstract}
Abstrak
Escherichia coli adalah salah satu bakteri penyebab diare. Alternatif pengobatan diare adalah bahan alam salah satunya menggunakan E. palmifolia, karena mengandung senyawa aktif seperti flavonoid, saponin, tannin dan alkaloid yang bersifat antibakteri. Tujuan penelitian ini untuk mengetahui aktivitas antibakteri ekstrak etil asetat umbi $E$. palmifolia terhadap pertumbuhan E. coli dan mengetahui adanya konsentrasi ekstrak etil asetat umbi E. palmifolia yang menyamai kontrol positif ciprofloxacin $5 \mu \mathrm{g}$ dalam menghambat pertumbuhan $E$. coli.

Jenis penelitian ini bersifat analitik eksperimental dengan pendekatan post test with control. Penelitian dilakukan di Laboratorium Bakteriologi STIKES pada bulan Februari sampai Juni 2019. Sampel penelitian adalah ektrak etil asetat umbi E. palmifolia dengan variasi konsentrasi $25 \%, 50 \%, 75 \%$ dan $100 \%$ yang diambil secara quota sampling. Kontrol positif yang digunakan adalah ciprofloxacin $5 \mu \mathrm{g}$ dan kontrol negatif menggunakan DMSO $10 \%$. Uji aktivitas antibakteri menggunakan metode disc diffusion. Analisis data statistik menggunakan Uji Kruskall-Wallis pada SPSS 16.0 .

Hasil penelitian menunjukkan semakin tinggi konsentrasi ekstrak etil asetat umbi E. palmifolia maka semakin besar diameter zona hambat yang dihasilkan. Dari masing-masing konsentrasi 25\%,50\%, 75\%, 100\% diperoleh diameter zona radikal $7,36 \mathrm{~mm}, 9,43 \mathrm{~mm}, 11,04 \mathrm{~mm}, 13,11 \mathrm{~mm}$. Hasil uji Kruskal-Wallis didapatkan nilai signifikansi $p=0.000$.

Variasi konsentrasi ekstrak etil asetat umbi E. palmifolia mampu menghambat pertumbuhan $E$. coli dan tidak ada konsentrasi ekstrak etil asetat umbi E. palmifolia yang menyamai kontrol positif ciprofloxacin $5 \mu \mathrm{g}$ dalam menghambat pertumbuhan $E$. coli.
\end{abstract}

Kata Kunci : Ekstrak etil asetat, Umbi E. palmifolia, E. coli, Ciprofloxacin $5 \mu \mathrm{g}$

\begin{abstract}
Escherichia coli is one of bacteria that causes diarrhea.An alternative treatment for diarrhea is a natural ingredient, one of which is E. palmifolia, because it contains active compounds such as flavonoids, saponins, tannins and alkaloids which are antibacterial. The aim of this study was to determine the antibacterial activity of E. palmifolia ethyl acetate extract on $E$. coli growth and to determine the concentration of ethyl acetate extract of tuberus $E$. palmifolia which matched the positive control of ciprofloxacin $5 \mu \mathrm{g}$ in inhibiting E. coli growth.
\end{abstract}


This type of research was analytical experimental with a post test with control approach. The research was done in the Microbiology Laboratory of STIKES Nasional from February until June 2019. The study sample was E. palmifolia etyl acetate extract with a concentration variation of $25 \%, 50 \%, 75 \%$ and $100 \%$ taken by quota sampling. The positive controls used were ciprofloxacin $5 \mu \mathrm{g}$ and negative control was DMSO $10 \%$. Antibacterial activity test used the disc diffusion method. Statistical data analysis used the Kruskall-Wallis Test on SPSS 16.0.

The results showed that the higher the concentration of ethyl acetate extract of $\mathrm{E}$. palmifolia tuber, the greater the diameter of the inhibition zone produced. From each concentration of $25 \%, 50 \%, 75 \%, 100 \%$ the radical zone diameter was $7.36 \mathrm{~mm}, 9.43$ $\mathrm{mm}, 11.04 \mathrm{~mm}, 13.11 \mathrm{~mm}$. The Kruskal-Wallis test results obtained a significance value of $p=0.000$.

Variation of E. palmifolia tuber ethyl acetate extract concentration was able to inhibit $E$. coli growth and there was no concentration of $E$. palmifolia ethyl acetate extract which matched the positive control of ciprofloxacin $5 \mu$ in inhibiting E. coli growth. Keywords: Ethyl acetate extract, Bulbs E. palmifolia, E. coli, Ciprofloxacin $5 \mu \mathrm{g}$

\section{Pendahuluan}

Diare adalah peningkatan pengeluaran tinja dengan konsistensi lebih lunak atau lebih cair dengan atau tanpa disertai lendir dan darah, terjadi paling sedikit tiga kali dalam 24 jam (Anggreli dkk., 2015). Menurut Basailin dkk (2018) penyakit diare merupakan penyebab kematian utama di dunia, terhitung 5-10 juta kematian/tahun. Prevalensi diare di Indonesia Tahun 2017 yaitu 4.274.790 penderita atau 60,4\% (Kemenkes RI, 2017). Proporsi kasus diare di Jawa Tengah Tahun 2017 sebesar 55,8\% dan Kota Surakarta 79,2\% (Dinkes Jateng, 2017).

Escherichia coli adalah salah satu bakteri penyebab diare, karena bakteri ini menghasilkan enterotoksin, merupakan bakteri gram negatif, berbentuk batang pendek, tidak berspora, berflagel dan bersifat patogen oportunistik (Zakki, 2015).

Penyakit diare yang disebabkan oleh Escherichia coli dapat diobati dengan antibiotik. Selain memberikan keuntungan antibiotic dapat memberikan dampak negatif bagi manusia yaitu dengan memicu sifat resistensi bakteri yang terus meningkat. Resitensi terhadap antibiotik dapat disebabkan karena antibiotik ini banyak digunakan masyarakat (Jurnalis dkk., 2009). Salah satu alternatif bahan alami yang mempunyai aktivitas sebagai antibakteri adalah Umbi Bawang Dayak (Eleutherine palmifolia (L.) Merr).

Menurut Puspadewi dkk (2013) E. palmifolia dapat digunakan untuk mengobati penyakit kulit, luka, batuk, mencret berdarah atau diare, sakit perut, disentri, radang poros usus, kanker colon, kanker payudara, menurunkan kolesterol, hipertensi, dan perangsang muntah.

Terbukti pada penelitian Suhartini (2017) menyatakan bahwa ekstrak etanol umbi E. palmifolia dapat menghambat pertumbuhan bakteri E. coli pada konsentrasi $25 \%, 50 \%$ dan $75 \%$ diperoleh zona hambat $6,6 \mathrm{~mm}$ sedangkan pada konsentrasi $100 \%$ diperoleh zona hambat $7,0 \mathrm{~mm}$.

Berdasarkan uraian di atas, maka peneliti tertarik untuk melakukan penelitian tentang "Aktivitas Antibakteri Ekstrak Etil Asetat Umbi Bawang Dayak (Eleutherine palmifolia (L.) Merr) Terhadap Pertumbuhan Escherichia coli Metode Difusi”.

\section{Metode Penelitian}

Penelitian ini menggunakan jenis penelitian yang bersifat analitik eksperimental dengan pendekatan post test with control untuk melihat zona hambat variasi konsentrasi ekstrak etil asetat umbi E. palmifolia terhadap pertumbuhan Escherichia coli yang dilakukan di Laboratorium STIKES Nasional pada bulan februari hingga juni 2019.

Alat

Mikroskop, inkubator, oven, rotary evaporator, autoklaf, dan jangka sorong.

Bahan

Umbi E. palmifolia berusia 3-4 bulan didapatkan dari Sky Argon Center Surakarta, biakan murni bakteri E. coli dari Laboratorium Mikrobiologi STIKES Nasional, DMSO 10\% (Kontrol Negatif), antibiotik ciprofloxacin5 $\mu \mathrm{g}$ (Kontrol Positif), etil asetat, media uji biokimia, cat 
gram, media MC, media MHA, media NA miring dan ragen uji fitokimia

\section{Tahapan Penelitian}

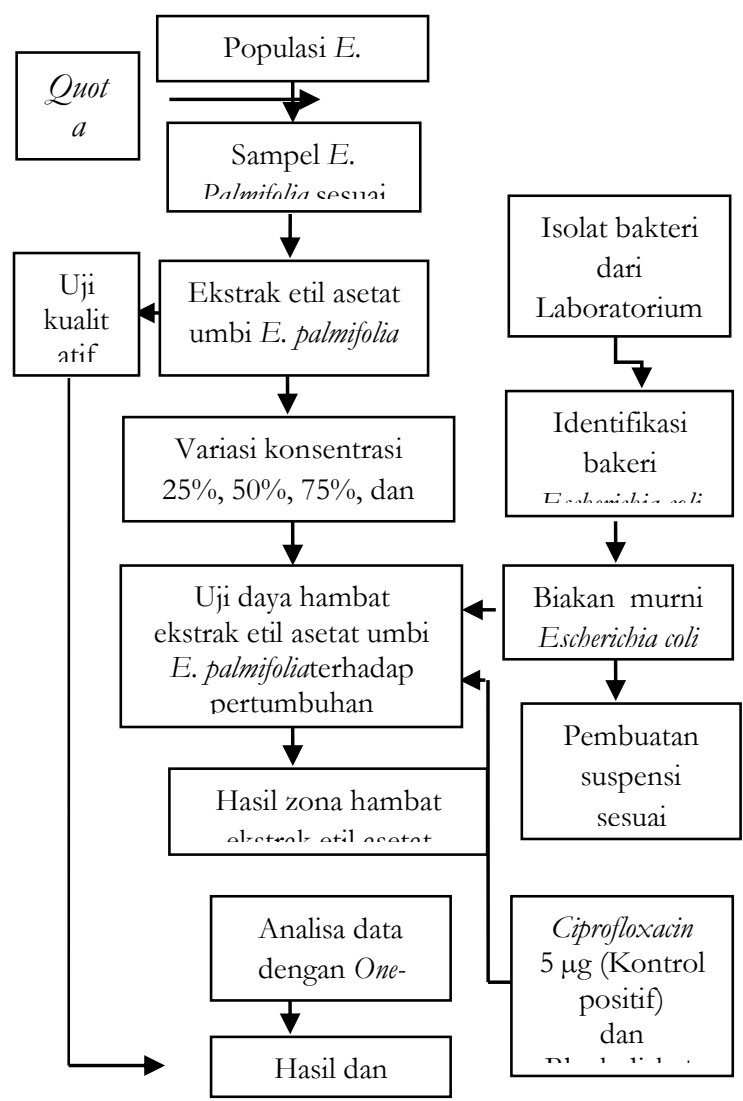

\section{Analisa Data}

Data yang diperoleh dari hasil pengukuran zona radikal Aktivitas Antibakteri Ekstrak Etil Asetat Umbi E. palmifolia Terhadap Pertumbuhan Escherichia coli dilakukan uji Shapiro-Wilk dan Levene, kemudian dianalisa dengan Kruskall-Wallis dilanjutkan dengan uji Mann-Whitney untuk mengetahui perbedaan bermakna.

\section{Hasil dan Pembahasan}

Hasil uji fitokimia ekstrak etil asetat umbi $E$. palmifolia

Tabel 1. Hasil uji fitokimia ekstrak etil asetat umbi

\section{Eleutherine palmifolia}

Hasil uji fitokimia (Tabel 1) menunjukkan bahwa ekstrak etil asetat umbi E. palmifolia mengandung senyawa metabolit sekunder seperti flavonoid, saponin, tanin dan alkaloid.

\begin{tabular}{|c|c|c|c|}
\hline & $\begin{array}{l}\text { Senyawa } \\
\text { Aktif }\end{array}$ & Hasil & Kesimpulan \\
\hline 1 & Flavonoid & $\begin{array}{l}\text { Terbentuk warna } \\
\text { jingga }\end{array}$ & + \\
\hline 2 & Saponin & $\begin{array}{l}\text { Terbentuk busa } \\
\text { yang tidak hilang } \\
\text { selama } 10 \text { menit }\end{array}$ & + \\
\hline 3 & Tanin & $\begin{array}{l}\text { Terbentuk warna } \\
\text { hitam }\end{array}$ & + \\
\hline 4 & Alkaloid & $\begin{array}{l}\text { Terbentuk endapan } \\
\text { jingga }\end{array}$ & + \\
\hline
\end{tabular}

\section{Hasil aktivitas antibakteri ekstrak etil asetat umbi} E. palmifolia

Tabel 2. Diameter zona hambat ekstrak etil asetat umbi Eleutherine palmifolia terhadap pertumbuhan Escherichia coli.

\begin{tabular}{|c|c|c|c|c|c|c|}
\hline \multirow{2}{*}{ Pengulangan } & \multirow{2}{*}{$\begin{array}{c}\text { Kontrol } \\
\text { negatif } \\
(\mathrm{mm})\end{array}$} & \multicolumn{4}{|c|}{$\begin{array}{l}\text { Zona Hambat (Radikal) Tiap } \\
\text { Varisai Konsentrasi (mm) }\end{array}$} & \multirow{2}{*}{$\begin{array}{c}\text { Kontro } \\
1 \\
\text { positif } \\
(\mathrm{mm})\end{array}$} \\
\hline & & $\begin{array}{l}25 \\
\%\end{array}$ & $50 \%$ & $75 \%$ & $100 \%$ & \\
\hline 1 & 6 & 8,5 & 9,8 & 12,2 & 14,1 & 35,1 \\
\hline 2 & 6 & 6,3 & 8,4 & 9,8 & 11,5 & 35,1 \\
\hline 3 & 6 & 7,4 & 10,6 & 11,1 & 14,1 & 35,6 \\
\hline 4 & 6 & 7,8 & 8,1 & 10,7 & 12,1 & 33,7 \\
\hline 5 & 6 & 7,1 & 10,1 & 11,2 & 14,8 & 33,1 \\
\hline 6 & 6 & 7,5 & 9,3 & 12,4 & 14,4 & 33,7 \\
\hline 7 & 6 & 7,4 & 8,3 & 9,4 & 11,8 & 33,4 \\
\hline 8 & 6 & 6,9 & 10,8 & 11,5 & 12,1 & 34,5 \\
\hline Rata-rata & 6 & $\begin{array}{c}7,3 \\
6\end{array}$ & 9,43 & 11,04 & $\begin{array}{c}13,1 \\
1\end{array}$ & 34,28 \\
\hline
\end{tabular}

Hasil aktivitas antibakteri ekstrak etil asetat umbi E. palmifolia memiliki kemampuan dalam menghambat pertumbuhan E. coli ditandai dengan terbentuknya zona radikal di sekitar disc pada semua variasi konsentrasi. Zona hambat (zona radikal) mulai terbentuk pada konsentrasi terkecil 25\% dengan ratarata diameter $7,36 \mathrm{~mm}$ hingga konsentrasi terbesar $100 \%$ rata-rata diameter sebesar $13,11 \mathrm{~mm}$. Hal ini menunjukkan bahwa variasi konsentrasi memiliki kemampuan yang berbeda sebagai antibakteri dalam menghambat pertumbuhan E. coli.

Penelitian ini menggunakan kontrol positif ciprofloxacin $5 \mu \mathrm{g}$ dan kontrol negatif disc blank yang diberi DMSO 10\%. Kontrol positif ciprofloxacin $5 \mu \mathrm{g}$ mampu membentuk zona hambat dengan rata-rata sebesar 34,28 $\mathrm{mm}$ pada pertumbuhan E. coli sehingga dapat dikatakan sensitif menurut CLSI (2018). Menurut Ersita dan Kardewi (2016) ciprofloxacin $5 \mu \mathrm{g}$ merupakan 
golongan antibiotik quinolone yang merupakan antibiotik broad spectrum, bersifat bakteriosidal (dapat membunuh bakteri) dengan cara menghambat proses replikasi DNA. Pada kontrol negatif disc blank yang diberi DMSO 10\% tidak membentuk zona hambat karena disc blank tidak memiliki aktivitas antibakteri.

Penelitian aktivitas antibakteri ekstrak etil asetat umbi E. palmifolia terhadap pertumbuhan E. coli dilakukan dengan metode disc diffusion. Zona radikal yang terbentuk diukur menggunakan jangka sorong. Hasil pada table 2 menunjukkan bahwa semakin tinggi konsentrasi zat antibakteri semakin besar zona radikal yang terbentuk.

Data yang diperoleh kemudian dianalisis menggunakan uji Kruskall-Wallis, hasil menunjukkan bahwa ekstrak etil asetat umbi E. palmifolia mampu menghambat pertumbuhan $E$. coli dengan signifikan $\mathrm{p}<0,05$. Kemudian hasil yang diperoleh dilanjutkan dengan uji Mann-Whitney untuk mengetahui kelompok mana yang memberikan perbedaan paling bermakna. Tabel 3. Hasil Uji Mann-Whitney Daya Hambat Ekstrak Etil Asetat Umbi Eleutherine palmifolia

\begin{tabular}{cc}
\hline Konsentrasi & $\begin{array}{c}\text { Rata-rata diameter zona gambat } \\
(\mathrm{mm})\end{array}$ \\
\hline Kontrol & $6^{\mathrm{a}}$ \\
negative & $7,36^{\mathrm{b}}$ \\
$25 \%$ & $9,43^{\mathrm{c}}$ \\
$50 \%$ & $11,04^{\mathrm{d}}$ \\
$75 \%$ & $13,11^{\mathrm{e}}$ \\
$100 \%$ & $34,28^{\mathrm{f}}$ \\
\hline
\end{tabular}

Keterangan : Huruf yang berbeda di belakang angka menunjukkan beda signifikan berdasarkan pada Uji Mann-Whitney dengan $\mathrm{p}<0,05$.

Hasil uji Mann-Whitney (Tabel 3) menunjukkan bahwa ada perbedaan konsentrasi ekstrak etil asetat umbi E. palmifolia dengan kontrol positif ciprofloxacin 5 $\mu \mathrm{g}$ dalam menghambat pertumbuhan E. coli (Tidak dapat menyamai kontrol positif ciprofloxacin $5 \mu \mathrm{g}$ ).

Ekstrak etil asetat E. palmifolia mampu menghambat pertumbuhan E. coli karena mengandung senyawa metabolit sekunder yang bersifat antibakteri seperti flavonoid, saponin, tannin dan alkaloid. Senyawa flavonoid bekerja dengan cara mendenaturasi protein, sehingga merusak struktur lipid dari DNA dan inti sel bakteri, menyebabkan bakteri lisis dan mati (Armanda dkk., 2017). Saponin dalam ekstrak E. palmifolia merusak permeabilitas dinding sel bakteri menyebabkan sitoplasma mengalami kebocoran hingga mengakibatkan kematian sel (Dominius, 2015). Senyawa tanin akan mengganggu pembentukan dinding sel bakteri dengan menghambat enzim DNA topoisomerase, menyebabkan sel bakteri tidak dapat terbentuk (Rizal dkk., 2018). Alkaloid dalam ekstrak bekerja dengan cara mengganggu komponen peptidoglikan sehingga dinding sel bakteri tidak terbentuk utuh dan menyebabkan kematian sel bakteri (Novaryatiin dkk., 2018).

Pembuatan serbuk simplisia umbi E. palmifolia dilakukan pengayakan dengan ayakan berukuran 60 mesh karena menurut Antari dkk., (2015) untuk memperkecil ukuran partikel ekstrak, semakin kecil ukuran serbuk yang digunakan maka semakin luas bidang kontak antara serbuk dengan pelarut, sehingga ekstrak akan lebih maksimal dan kandungan senyawa metabolit tersari secara optimal. Serbuk simplisia umbi E. palmifolia diekstraksi menggunakan metode maserasi. Keuntungan dari metode maserasi adalah dapat menghasilkan ekstrak dalam jumlah banyak serta dapat menghindari rusaknya senyawa metabolit sekunder akibat pemanasan, cara pengerjaan yang sederhana dan alat yang mudah didapatkan (Wardhani dan Sulistyani, 2012).

Maserasi dilakukan selama 5 hari, karena menurut Putri dkk., (2013) 5 hari adalah waktu optimal suatu pelarut dapat menarik senyawa metabolit sekunder yang terkandung didalam ekstrak. Kemudian dilakukan proses remaserasi selama 2 hari agar senyawa yang tersari lebih banyak. Pengadukan pada proses maserasi bertujuan untuk meratakan konsentrasi larutan, sehingga kondisi jenuh yang terlalu cepat dapat dihindari dan proses penyarian lebih maksimal (Wardhani dan Sulistyani, 2012). Pelarut yang digunakan dalam penelitian ini adalah etil asetat. Etil asetat adalah pelarut yang bersifat semi polar sehingga dapat menarik senyawa metabolit sekunder yang bersifat polar dan non polar.(Putri dkk., 2013).

\section{Kesimpulan}

Ekstrak etil asetat umbi E. palmifolia mampu menghambat pertumbuhan Escherichia coli dan ada perbedaan konsentrasi ekstrak etil asetat umbi $E$. palmifolia dengan kontrol positif ciprofloxacin $5 \mu \mathrm{g}$ dalam menghambat pertumbuhan E. coli (Tidak dapat menyamai kontrol positif ciprofloxacin $5 \mu \mathrm{g})$. 


\section{Daftar Pustaka}

Anggreli, C.A., Anggaraini, D., \& Savira, M. 2015.

Gejala Penyerta pada Balita Diare dengan Infeksi Entheropathogenic Escherichia coli (EPEC) di Puskesmas Rawat Inap Kota Pekanbaru. JOM FK 2(1) : 1-7

Antari, N. M. R. O., Wartini, N.M., dan Mulyani, S. 2015. Pengaruh Ukuran Partikel dan Lama Ekstraksi Terhadap Karakteristik Ekstrak Warna Alami Buah Pandan. Jurnal Rekayasa dan Manajemen Argoindustri. 3 (4) : 30-40

Armanda, F., Ichrom, M.Y., Yanuar Ichrom N, \& Budiarty, L.Y. 2017. Efektivitas Daya Hambat Bakteri Ekstrak Bawang Dayak Terstandarisasi Flavonoid Terhadap Enterococcus faecalis (In Vitro). Journal kedokteran gigi 2 (2) : $183-187$

Basailin, M.., Agrina., \& Zulfitri, R. 2018. Hubungan Durasi Riwayat Pemberian Asi Terhadap Kejadian Diare Pada Bayi. JOM FKP $5(2): 98-\quad 104$

Clinical and Laboratory Stabdards Institute (CLSI). 2018. Performance Standards for Antimicrobial Susceptibility Testing. 28 $8^{\text {th }}$ ed CLSI supplement M100. ISBN 1-56238-839-8 (Electronic). CLSI Institute : Pennsylvania

Dinkes Jateng. 2017. Profil Kesehatan Provinsi Jawa Tengah Tahun 2017. Dinkes, Jateng

Dominius, A. 2015. Uji Aktivitas Antibakteri Kombinasi Infusa Umbi Bawangdayak (Eleutherine americana (Aubl.) dan Daun Mangga Bacang (Mangifera foetida L.) Terhadap Staphylococcus aureus Secara In Vitro. Skripsi. Universitas Tanjungpura, Pontianak

Ersita dan Kardewi. 2016. Uji Efektivitas Antibakteri Fraksi Aktif Daun Sirsak (Annona muricata Linn) Terhadap Bakteri Escherichia coli. Jurnal Kedokteran dan Kesehatan. 3 (2) : 97-107
Huliselan, Y.M., Runtuwene, M.R.J., dan Wewengkang, D.S. 2015. Aktivitas Ekstrak Etanol, Etil Asetat, dan n-Heksan Dari Dun Sesewanua (Clerodendron squamatum $V$ abl). Jurnal Ilmiah Farmasi 4 (3) : 155-163

Jurnalis, Y.D., Sayoeti, Y., dan Aslinar. 2009.

Pola Resistensi Kuman Penyebab Diare Terhadap Antibiotika. Artikel Penelitian. Majalah Kedokteran Andalas, Padang

Kemenkes RI. 2017. Profil Kesehatan

Indonesia. Kementrian Kesehatan Republik Indonesia, Jakarta

Novaryatiin, S., Pratiwi, A.M., dan Ardhany, S.D. 2018. Uji Daya Hambat Ekstrak Etanol Bawang Dayak (Eleutherine bulbosa (Mill.) Urb.) Terhadap Bakteri Staphylococcus epidermidis. Anterior Jurnal $18 \quad$ (1) : $92-97$

Putri, W. S., Warditiani, N.K., dan Larasanty, L. P. F. 2013. Skrining Fitokimia Ekstrak Etil Asetat Kulit Buah Manggis (Garcinia mangostana L.). Artikel Ilmiah. Universitas Udayana, Bali.

Puspadewi, R., Adirestuti, P., dan Menawati, R. 2013. Khasiat Umbi Bawang Dayak (Eleutherine Palmifolia (L.) Merr.) Sebagai Herbal Antimikroba Kulit. Jurnal Ilmiah Farmasi, 1(1) : 31-37

Rizal, N.M., Nurhaeni., \& Ridhay, A. 2018. Aktivitas Antibakteri Ekstrak Daun Mayana (Coleus Atropurpureus [L] Benth) Berdasarkan Tingkat Kepolaran Pelarut. KOVALEN 4(2): 180-189

Suhartini. 2017. Keefektifan Ekstrak

Eleutherine palmifolial terhadap Daya Hambat Pertumbuhan bakteri S.aureus dan E.coli.Journal Mabakam Medical Laboratory Technology. $2(1): 10-17$ 
Wardhani, L, K. dan Sulistyani, N. 2012. Uji Aktivitas Antibakteri Ekstrak Etil Asetat Daun Binahong (Anredera scandens (L.) Moq.) Terhadap Shigella flexneri Beserta Profil Kromatografi Lapis Tipis. Jurnal Ilmiah Kefarmasian 2 (1):1-16
Zakki, G.I. 2015. Pengetahuan Dan Perilaku Preventif Terhadap Bakteri E-Coli Pada Masyarakat Kecamatan Gondomanan di Kota Yogyakarta Skripsi. Universitas Negeri Semarang 